Archived version from NCDOCKS Institutional Repository http://libres.uncg.edu/ir/asu/

\title{
Appalachỉan
}

$\overline{\text { B O O N E, N O R T H C A R O L I N A }}$

\section{North Carolina, Pioneer In American Nursing}

\author{
By: Phoebe Pollitt, PhD and Wendy Miller, DNP
}

\begin{abstract}
On March 3, 1903, before women in the United States had the right to vote or were allowed to hold public office, the state legislature in North Carolina, at the urging of the newly formed North Carolina State Nurses Association (NCSNA), passed the first law in the nation permitting nurses to become licensed. Later that year, New York became the first state to mandate (as opposed to permitting) nursing licensure, a move North Carolina wouldn't make until 1965. But the 1903 North Carolina law called for the establishment of educational and practice standards for nurses wishing to take the newly created RN examination and to use the title "registered nurse." On June 4, 1903, Josephine Burton of Craven County became the first RN in North Carolina, and therefore the first in the United States.
\end{abstract}

Pollitt, P. and Miller, W. (2010). "North Carolina, Pioneer in American Nursing." AJN, American Journal of Nursing: February 2010 - Volume 110 - Issue 2 - p 70-71. doi: 10.1097/01.NAJ.0000368066.92921.be. Publisher version of record available at: https://journals.Iww.com/ajnonline/Fulltext/2010/02000/ North_Carolina,_Pioneer_in_American_Nursing.41.aspx. NC Docks re-print is not the final published version. 

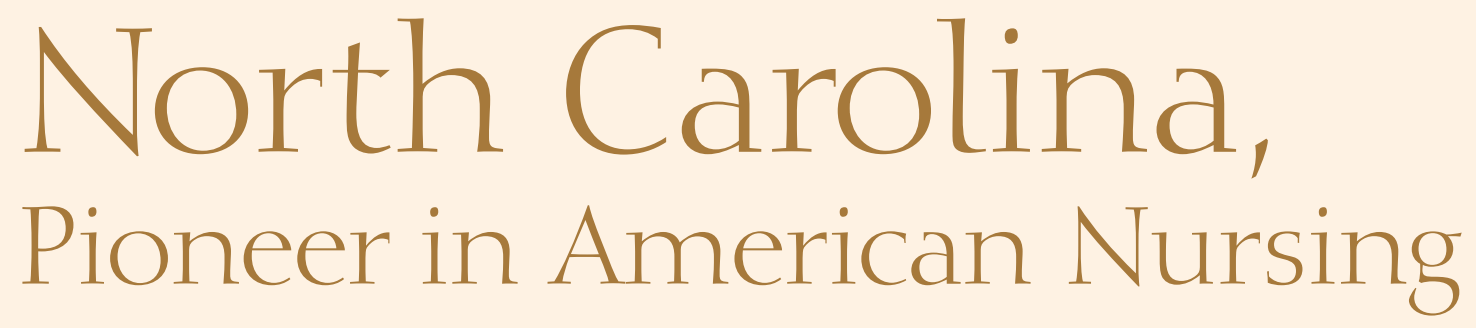

Passage of the first nurse registration law in the United States.

[T] he trained nurse of to-day has no legal standing. . . She does not belong to a profession, she is not classed even with the graduates of a technical school, and the woman who has taken up nursing without any training, or who has been discharged from a training-school for serious cause, has the same right to call herself a trained nurse before the law as she who has given three years of hard work and hard study. ${ }^{1}$

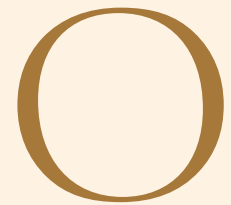

$\mathrm{n}$ March 3, 1903, before women in the United States had the right to vote or were allowed to hold public office, the state legislature in North Carolina, at the urging of the newly formed North Carolina State Nurses Association (NCSNA), passed the first law in the nation permitting nurses to become licensed.

Later that year, New York became the first state to mandate (as opposed to permitting) nursing licensure, a move North Carolina wouldn't make until 1965. But the 1903 North Carolina law called for the establishment of educational and practice standards for nurses wishing to take the newly created $\mathrm{RN}$ examination and to use the title "registered nurse." ${ }^{2} \mathrm{On}$ June 4, 1903, Josephine Burton of Craven County became the first RN in North Carolina, and therefore the first in the United States. ${ }^{3}$

\section{ONE NURSE'S VISION}

This important event in American nursing came about largely as a result of the efforts of one woman, Mary Lewis Wyche, the founder and first president of the NCSNA. ${ }^{4}$ The greatest source of information on Wyche comes from her own book, The History of Nursing in North Carolina, which she had nearly finished but which hadn't yet been published when she died in 1936. ${ }^{5,6}$ First-person accounts of historical events are often colored by what the author chooses to recount or conceal. Although using Wyche herself as a source is somewhat problematic, much of her account is validated by other sources, including AJN., ${ }^{2,7-10}$

Wyche was born in rural Vance County, North Carolina, in 1858. As a young woman she knew she wanted to become a nurse, but her training was thwarted by both family obligations and the absence of nursing schools in her state. Like many other women in her situation at the time, when she finally received her nursing education, she did so in the Northeast, graduating from Philadelphia General Hospital Training School in 1894. Upon graduation, she returned to the Tarheel State and helped revolutionize the nursing profession.

Wyche's accomplishments. In addition to helping to write, publicize, and pass the first nurse licensing law in the nation and writing the only book about the history of nursing in North Carolina, Wyche established the first nursing school in North Carolina, the Rex Hospital School of Nursing in Raleigh, and 
helped found the NCSNA, serving as its first president. ${ }^{4}$

According to Wyche's book, she had attended a meeting of the International Council of Nurses in Buffalo, New York, in the spring of 1901 and had been inspired by discussions of "legislation and registration." ${ }^{6}$ Wyche returned to Raleigh determined to form a statewide nursing organization dedicated to using nursing registration and legislative advocacy to improve the profession and patient care. Soon the newly created Raleigh Nurses Association started work to form the NCSNA. ${ }^{6}$ In 1902 the Raleigh group invited every nurse it could find in North Carolina to a meeting in Raleigh during the week of the state fair, which would be an enticement in and of itself and a time when the railroads offered reduced fares. Fourteen nurses from across the state met with members of the Raleigh Nurses Association on October 28, 1902, and the NCSNA was launched. ${ }^{6}$

The first item on the meeting's agenda was the creation of a law to set standards for people using the title "registered nurse" when practicing nursing in the state. With the help of friendly legislators and many lay people interested in improving the quality of health care in North Carolina, the group drafted a bill and introduced it in the 1903 state legislative session. The bill met with some opposition from hospital administrators who claimed it was unnecessary and would unfairly tax both poor women and the hospitals, and from at least one nurse who claimed it was merely an attempt to stifle "the competition." ${ }^{11}$ A revised version of the bill passed, however, and was signed into law by the reform-minded governor, Charles Aycock. ${ }^{6}$

The bill established the creation of the Board of Examiners of Trained Nurses of North Carolina. In its initial iteration, the board was composed of two physicians and three RNs elected by their respective professional organizations (Wyche herself was one of the first RNs on the board). Any applicant considered to be of good moral character who met the established educational criteria was examined "in the elements of anatomy and physiology, in medical, surgical, obstetrical, and practical nursing, invalid cookery, and household hygiene." ${ }^{2}$ (The law also allowed practicing nurses to be grandfathered into licensure if they had sufficient written support of medical professionals.) Successful applicants were awarded a certificate, or license, by the board, which they then presented to the clerk of the superior court in any county in North Carolina in which they wished to practice. Their names were entered in a book "kept in [the clerk's] office for this purpose and marked 'Register of Trained Nurses,"” and each RN was issued a certificate of registration under the seal of the court in that county. ${ }^{2}$ Under the new law, using the title "Registered Nurse" or "R.N." without a registration certificate was a misdemeanor, punishable by a fine of up to $\$ 50$ or imprisonment for not more than 30 days. ${ }^{2,12}$

\section{NORTH CAROLINA'S LEGACY}

North Carolina became a model for other states that were struggling to create laws and structures to ensure minimum standards of nursing. These first efforts by the NCSNA and the board of examiners were the beginning of more than a century of hard work with the state's General Assembly to upgrade the standards and scope of the nursing practice in North Carolina. The vision and drive it took for a group of female nurses from a rural, politically conservative, southern state to form a professional association to push for reforms that would benefit themselves, their fellow nurses, and the patients of North Carolina-not to mention the rest of the country-can inspire nurses today. The impulse to improve standards of care is echoed in current efforts to enhance the profession. Conscious of the past, committed to living in the present for the sake of the future, with imagination and determination, we can continue to elevate nursing to levels nurses will honor 100 years from now.

Phoebe Pollitt and Wendy Miller are both assistant professors of nursing in the Department of Nursing at Appalachian State University in Boone, NC. Contact author: Phoebe Pollitt, pollittpa@appstate.edu.

\section{REFERENCES}

1. Palmer SF. Editorial comment. The A,B,C of state registration. Am J Nurs 1902;3(2):156-8.

2. North Carolina bill: became a law March 2, 1903. Am J Nurs 1907;7(4):274.

3. A joint resolution honoring the life and memory of Mary Lewis Wyche ... on the one hundredth anniversary of professional nursing in North Carolina. 2003.

4. Birnbach N. Mary Lewis Wyche, 1858-1936. In: Bullough VL, et al., editors. American nursing: a biographical dictionary. New York: Garland; 1992. vol. 2. p. 366-7.

5. Obituaries. Mary L. Wyche. Am J Nurs 1936;36(10):1064.

6. Wyche ML. The history of nursing in North Carolina. Chapel Hill: University of North Carolina Press; 1938.

7. Thornton ME. Official reports of societies: North Carolina State Nurses Association. Am J Nurs 1902;3(1):54.

8. Thornton ME. Official reports of societies: the North Carolina state meeting. Am J Nurs 1902;3(3):221.

9. Thornton ME. Official reports of societies: North Carolina state nurses bill. Am J Nurs 1903;3(6):476.

10. Thornton ME. Official reports of societies: the North Carolina bill. Am J Nurs 1903;3(7):562.

11. Nurses hard battle: bill for trained nurses torn to pieces. Raleigh News and Observer 1903 Feb 10.

12. Shannon ML. Nurses in American history. Our first four licensure laws. Am J Nurs 1975;75(8):1327-9. 